\title{
Entrepreneurship in Tourism in Rural Problem Areas. Case Stage of the West Pomeranian Voivodeship
}

\author{
Krzysztof SALA
}

Pedagogical University of Cracow, Cracow; Poland; krzysztofsal@onet.pl

\begin{abstract}
Rural areas in many countries are areas with lower levels of development and quality of life. Therefore, efforts to develop entrepreneurship and innovation in these areas are of particular importance. This applies especially to those rural areas, which for many years were areas of special problems related to political changes. The aim of the publication is to present the situation of rural problem areas in the West Pomeranian Voivodeship in Poland, as well as to present innovative examples of developing entrepreneurship in these areas and their effects. The scientific thesis of the publication is that thematic villages in the West Pomeranian region are an important element in stimulating entrepreneurship in rural problem areas. The paper presents the current economic situation of rural areas in the West Pomeranian region, factors affecting the activation of entrepreneurship. Particular attention was paid to showing examples of entrepreneurial solutions in rural areas. The article was created using compact materials, statistical data as well as netographic information. The research method used in the publication is the analysis of existing data and a telephone interview with representatives of thematic villages. Research results positively verify the thesis that thematic villages significantly contribute to stimulating entrepreneurship in rural areas
\end{abstract}

Keywords: development; non-governmental organizations; local community; rural tourism; thematic villages

JEL Classification: A10; Q10; R11

\section{Introduction}

The development of entrepreneurship in non-urban areas is the subject of research of many scientists. The subject matter appeared in publications of such authors as e.g. W. Kamieńska (Kamieńska 2015), K. Krajewski, J. Śliwa (Krajewski and Śliwa 2004), F. Kapusta (Kapusta 2008), D. Knecht (Knecht 2009), J. Sikora (Sikora 2012).

Rural areas are often characterized by a lower level of development, innovation, and thus also quality of life. The concern for equal opportunities and the elimination of rural development disparities in comparison with cities should be an important element of economic policy. It may cause the elimination of many negative phenomena occurring in the countryside, in particular its depopulation.

The aim of the publication is to present the current situation of rural problem areas in the West Pomeranian Voivodeship in Poland, as well as to present interesting examples of developing entrepreneurship in these areas and their consequences.

The scientific thesis of the publication is that thematic villages in the West Pomeranian region are an important element in stimulating entrepreneurship in rural problem areas.

The paper presents the current economic situation of rural areas in the West Pomeranian region, factors affecting the activation of entrepreneurship. Particular attention was devoted to showing examples of entrepreneurial solutions on the example of thematic villages.

\section{Methodology}

The article was created using book materials, statistical data as well as netographic information. The research method used in the publication is the analysis of existing data and a telephone interview with representatives of thematic villages. The studies covered the period from 2013 to 2019. In defining 
the nature of rural areas, the OECD definition was used. The theme village was defined as a town whose development is based on the use of a specific idea, constituting a tourist product, enabling the creation of additional income for residents. Research results positively verify the thesis that thematic villages significantly contribute to stimulating entrepreneurship in rural areas.

\section{Specificity of Rural Areas in the West Pomeranian Region}

West Pomeranian Voivodeship is located in the northwest of Poland, on the coast of the Baltic Sea. It covers an area of 22,922,48 $\mathrm{km}^{2}$. According to data from June 30, 2019, it had about 1.7 million inhabitants. The seat of the voivodship authorities is Szczecin. West Pomeranian is the westernmost voivodship in Poland (GUS 2019).

Rural areas have a strong impact on the nature of the region in question. In 2016, the share of rural areas in the West Pomeranian Voivodeship was $93.8 \%$ and was higher than the national average (93.1\%). In contrast, communes below 5000 inhabitants inhabited by rural population constituted $58.3 \%$, which was the third result in Poland, with the national average of $36.7 \%$ (GUS 2017).

According to the latest data for 2010, there were 59.6 thous. farms in the West Pomeranian Voivodeship, of which $99.24 \%$ were individual. Most often (i.e. $12 \%$ ) the farm had an area of 5 to 10 ha for arable land. In the West Pomeranian Voivodeship, arable land $(78.8 \%)$, grassland $(20.7 \%)$ and orchards $(0.5 \%)$ predominate in terms of agricultural use. In 2010, the total sown area in the voivodship covered 662.0 thous. ha, of which the most $(25.2 \%)$ was sown by wheat. The harvest of cereals alone amounted to 1881.0 thous. tons, which accounted for $6.8 \%$ of cereal crops from all over Poland (GUS 2010).

The soils of the West Pomeranian Voivodship are characterized by strong typological and bonitic diversity as well as agricultural suitability. Medium quality soils (class IV a and IV b) occupy the most - over $51.2 \%$ of the area. The smallest surface is covered by very good and good soils (class I, II). This situation directly affects the profitability of farming, which can be considered average in this case (Mocek 2015).

When discussing the current specificity of rural areas, account should be taken of past events and historical background. The territories of the present West Pomeranian Voivodeship did not enter Poland until after World War II. As a result of hostilities, as well as the robbery policy followed immediately, many villages, farms or houses underwent extensive devastation and looting. The former German private farms were mostly transferred to the state and transformed into state-owned farms. Individual farming was replaced by joint work. This form of agricultural activity changed the image of the West Pomeranian village and the mentality of its inhabitants for many years. Despite the low economic efficiency, state-owned farms operated until the early 1990s. (Pilichowski and Podedworna 2011).

The process of economic changes that have taken place since the beginning of the 1990s has contributed to major changes that have affected the economy and rural communities in the West Pomeranian region. As a result of the economic transformation the unprofitable state-owned farms were gradually liquidated. The negative effects of economic transformation in these areas include the systematic increase in unemployment, the destruction of the former state economic infrastructure, social and living base as well as cultural and educational centers. For many years to come, many rural areas of the West Pomeranian Voivodeship were problem areas and even social exclusion (Jasiulewicz 2011). Many people could not find their place in the new reality, and they were not provided with sufficient support and prospects for new employment from the state.

Taking into account historical conditions, specificity, as well as the problems of rural areas of the West Pomeranian region that have arisen over the years of political changes, creating the right conditions for the development of entrepreneurship in their areas is a very important challenge. The need to counteract negative phenomena occurring in the countryside, such as:

- rural depopulation processes and the escape of young people into cities,

- increase in the level of unemployment, including particularly persistent one,

- progressive degradation and pauperization,

- disappearance of cultural traditions and social ties (Smętkowski et al. 2008). 
A serious threat to the rural areas of the West Pomeranian Voivodship are also the prospects of Poles moving and settling in neighboring Germany. Due to the escape of many young people to the western parts of the country, the German self-government authorities have a policy of encouraging Polish citizens to settle in the border towns of their country. Settlers are attracted by competitive property prices or strong support in entrepreneurship creation. The problem particularly concerns young people who are particularly valuable for the development of the Polish countryside (Rudewicz 2017).

\section{Development of Entrepreneurship in Rural Areas of the West Pomeranian Voivodeship}

Among the possible tools to stimulate entrepreneurial activity in rural areas include:

- supporting various forms of economic activity, especially in areas with high unemployment,

- enabling the use of EU aid funds, including from Rural Development programs,

- creating conditions for the full use of existing local potential,

- providing support in innovative activities,

- support for local self-government bodies of various forms of professional activity (Czapiewska 2011)

When considering rural enterprise development programs, local conditions should be taken into account. It becomes necessary to analyze the situation on the local labor market, the level of infrastructure development and natural resources. In addition, efforts should be made to change human mentality through education and training programs (Bański 2017).

Development prospects for rural areas of the West Pomeranian Voivodeship are not even. In a privileged position are those villages that are located near large urban centers, as well as those located in the Baltic Sea coastal strip, showing great interest on the part of tourists or those that have extremely favorable conditions for the development of agriculture (e.g. the Pyrzyce region) (Rumiński 2002).

In recent years, many West Pomeranian villages have shown great dynamics of change, and their inhabitants have entrepreneurial abilities. Rural areas and municipalities located on the Baltic Sea coast belt coped efficiently with investments by investing in infrastructure and tourism development (e.g. Mielno, Dziwnów). Some of them became one of the richest communes in Poland (Rewal). Favorable changes in this area are illustrated by the development of local agritourism and rural guest rooms (Table 1).

Table 1. The number and number of beds in agritourism farms and guest rooms by regions in Poland in selected years.

\begin{tabular}{cccccc}
\hline Voivodeship & $\mathbf{2 0 1 3}$ & $\mathbf{2 0 1 5}$ & $\mathbf{2 0 1 6}$ & $\mathbf{2 0 1 7}$ & $\mathbf{2 0 1 8}$ \\
\hline Lower Silesia & $209 / 4366$ & $194 / 4097$ & $213 / 4681$ & $212 / 4737$ & $272 / 5733$ \\
Kuyavian-Pomeranian & $33 / 632$ & $47 / 873$ & $54 / 1027$ & $61 / 1287$ & $65 / 1263$ \\
Lublin & $57 / 929$ & $71 / 1280$ & $88 / 1610$ & $91 / 1670$ & $116 / 2209$ \\
Lubuskie & $38 / 663$ & $33 / 542$ & $37 / 638$ & $40 / 719$ & $45 / 867$ \\
Lodz & $44 / 715$ & $52 / 898$ & $61 / 1163$ & $51 / 1079$ & $54 / 1131$ \\
Lesser Poland & $540 / 12819$ & $545 / 13334$ & $545 / 13658$ & $554 / 14485$ & $531 / 14241$ \\
Masovian & $72 / 1274$ & $69 / 1332$ & $75 / 1547$ & $78 / 1704$ & $106 / 2474$ \\
Opole & $23 / 364$ & $29 / 418$ & $29 / 440$ & $25 / 426$ & $34 / 722$ \\
Podkarpackie & $120 / 2058$ & $114 / 1990$ & $124 / 2321$ & $122 / 2379$ & $153 / 3073$ \\
Podlasie & $81 / 1197$ & $87 / 1437$ & $78 / 1309$ & $79 / 1377$ & $82 / 1555$ \\
Pomeranian & $608 / 12500$ & $634 / 13669$ & $671 / 14503$ & $669 / 14943$ & $678 / 15692$ \\
Silesian & $124 / 2706$ & $123 / 2684$ & $126 / 2814$ & $120 / 2679$ & $128 / 2781$ \\
\hline
\end{tabular}




\begin{tabular}{cccccc}
\hline Holy Cross & $42 / 616$ & $52 / 849$ & $49 / 804$ & $47 / 830$ & $47 / 877$ \\
Warmia - Masurian & $111 / 1836$ & $129 / 2060$ & $126 / 2032$ & $116 / 1930$ & $117 / 1986$ \\
Greater Poland & $101 / 1632$ & $94 / 1644$ & $90 / 1627$ & $88 / 1585$ & $87 / 1555$ \\
West Pomeranian & $420 / 8943$ & $414 / 9585$ & $432 / 10216$ & $476 / 11409$ & $535 / 12849$ \\
Poland & $2623 / 53230$ & $2687 / 66068$ & $2679 / 57594$ & $2829 / 63239$ & $3050 / 69008$ \\
\hline
\end{tabular}

The data contained in Table 1 clearly show that the West Pomeranian Voivodeship is at the forefront of the country in terms of the level of development of the rural accommodation base. In addition, this database has been constantly developing in recent years. It is also worth analyzing the state of use of the rural accommodation base, which is presented in Table 2.

Table 2. Number of people using lodging at agritourism farms and foreign guests in selected years.

\begin{tabular}{|c|c|c|c|c|c|}
\hline Voivodeship & 2013 & 2015 & 2016 & 2017 & 2018 \\
\hline Lower Silesia & $66329 / 8560$ & $78824 / 2590$ & $86738 / 4946$ & $101473 / 6272$ & $117062 / 3916$ \\
\hline Kuyavian-Pomeranian & $9001 / 79$ & $13538 / 276$ & $15487 / 215$ & $17581 / 329$ & $25742 / 913$ \\
\hline Lublin & $16152 / 2051$ & 27370/1789 & $31984 / 2520$ & $31339 / 1551$ & $4085 / 1870$ \\
\hline Lubuskie & $9684 / 1728$ & $9939 / 653$ & $10585 / 716$ & $13259 / 1120$ & $16256 / 1559$ \\
\hline Lodz & $19190 / 3572$ & $18574 / 2142$ & $18842 / 1594$ & $14339 / 562$ & $15193 / 654$ \\
\hline Lesser Poland & $144078 / 43570$ & $164811 / 17126$ & $210501 / 26880$ & $245981 / 35190$ & $263675 / 43249$ \\
\hline Masovian & $21614 / 4380$ & $23395 / 3091$ & $33155 / 4172$ & $43695 / 5439$ & $53490 / 5321$ \\
\hline Opole & $3032 / 1232$ & $4624 / 474$ & $4343 / 636$ & $4231 / 687$ & $3607 / 423$ \\
\hline Podkarpackie & $23129 / 1744$ & $25127 / 1231$ & $31696 / 1523$ & $37167 / 2022$ & $47890 / 3279$ \\
\hline Podlasie & $12506 / 2199$ & $16928 / 654$ & $17537 / 860$ & $19591 / 1138$ & $18801 / 1185$ \\
\hline Pomeranian & $106820 / 12955$ & $125376 / 3668$ & $141545 / 4717$ & $160037 / 8440$ & $182577 / 9126$ \\
\hline Silesian & $57029 / 3590$ & $58387 / 1463$ & $53933 / 2062$ & $53016 / 2537$ & $67985 / 3256$ \\
\hline Holy Cross & $4747 /-$ & $7786 / 33$ & $8838 / 41$ & $10524 / 525$ & $16454 / 737$ \\
\hline Warmia - Masurian & $15296 / 4747$ & 19385/1701 & $23754 / 2447$ & $20851 / 1840$ & $22384 / 1273$ \\
\hline Greater Poland & $16343 / 1133$ & $19845 / 669$ & 19745/1009 & 22135/1856 & 29354/1521 \\
\hline West Pomeranian & $57700 / 18068$ & $82190 / 8975$ & 101102/10409 & $108295 / 12044$ & $145796 / 16199$ \\
\hline Poland & $582350 / 109590$ & $685139 / 46535$ & $769793 / 61248$ & $903514 / 81552$ & $1067121 / 94481$ \\
\hline
\end{tabular}

The data contained in Table 2 indicate that the rural accommodation base of the West Pomeranian Voivodeship is characterized by high and, moreover, growing interest from tourists and foreign guests.

Some rural communes in the West Pomeranian Region have decided to invest and thus benefit from renewable energy (e.g. Zagórze, Tymień, Jagnitkowo, Karścino). The voivodship in question ranks first in terms of installed capacity of wind farms in Poland, which brings economic benefits (Figure 1). 


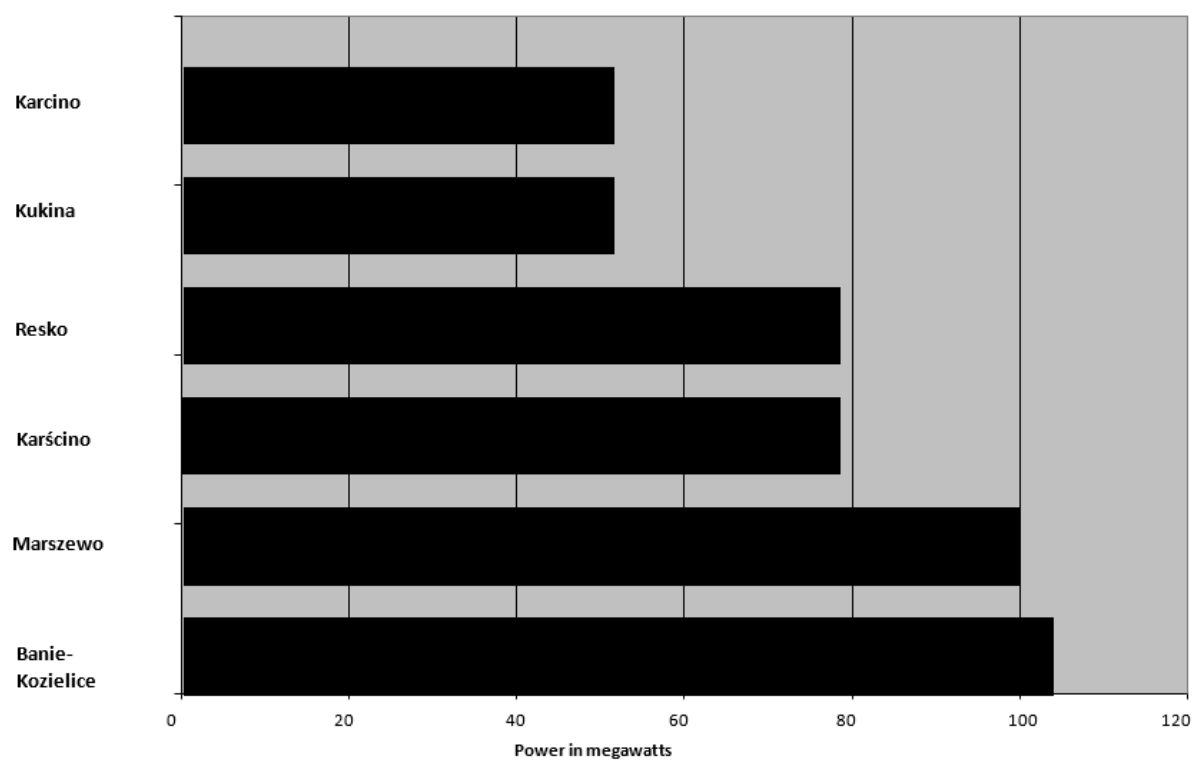

Figure 1. The largest wind farms in the West Pomeranian Voivodeship in 2019.

To complement the picture of the development of rural communes in the West Pomeranian Voivodeship, it should be added that some of them did not cope with economic problems and were liquidated over time (e.g. the Ostrowice commune).

\section{Ways to Activate Entrepreneurial Activities in Rural Areas of the West Pomeranian Voivodeship}

Of the many initiatives to develop entrepreneurship in the rural areas of the region, special attention deserves those little-known and characterized by a high level of innovation. Such ideas should certainly include the creation and operation of thematic villages (Biziuk 2009).

Theme villages are villages with a leitmotif. They focus on one idea and theme. They are an innovative way to revive the rural economy and provide alternative and often significant income to rural residents. Establishing them does not involve high costs, and joint work involves entire rural families (Sala 2016). Thematic villages are places that in the new formula try to adapt to the modern world and at the same time invent a new way of living and earning (Idziak 2008). It is no longer drawing income from typical farming or farming. Thematic villages earn on selling services, symbolic values, emotions, creativity and knowledge (Gangewere 1999).

The West Pomeranian Region was a pioneer in the implementation of this type of projects on a larger scale in Poland (Idziak 2004). Among the first thematic villages in the region we can include:

- Dąbrowa - a village of healthy living,

- Iwięcino - village of the end of the world,

- Paproty - a village of labyrinths and sources,

- Podgórki - a village of fairy tales and fun,

- Sierakowo Sławieńskie - the village of Hobbits.

All of the above towns are centers which as a result of political changes have been problem areas for many years. They are located near Koszalin, but they do not lie on the Baltic coast and therefore cannot count on income from inbound holiday tourism. Dąbrowa, Iwięcino and Sierakowo Sławieńskie are sołeckie villages in the commune of Sianów. Paproty and Podgórki are the villages of the Malechowo commune. The number of localities does not exceed 400 inhabitants (GUS 2019).

The mentioned thematic villages were founded in 2000 on the initiative of a sociologist and specialist in the field of rural development, Dr Wacław Idziak from the Koszalin University of Technology, as a result of the "Thematic villages" project implemented by the "Together" Partnership and co-financed from European Funds (Zielazna 2016). 
The offer provided by all thematic villages includes such elements as:

- educational paths,

- field games,

- workshop classes,

- farm visits, including educational holdings.

Evidence of interest in the offer of the discussed villages is the fact that only from May to December 2008, the services of all five thematic villages were used by a total of approximately 16,000 people (Idziak 2009).

In addition to some common elements, each of the thematic villages has a unique tourist offer to offer. The village of Dąbrowa promotes fashion for a healthy culinary offer based on its own traditional food products. It offers its guests honey, syrups, meats and herbs. Iwięcino offers its tourists a unique opportunity to reflect on final matters. The village's theme was taken from the painting of the Last Judgment in the local medieval church. The Paproty village, in turn, focused on organized games based on following or building your own mazes. In contrast, Podgórki, as part of its theme, invites you to theater, juggling and cycling events.

Sierakowo Sławieńskie deserves special attention among these thematic villages. Sierakowo Sławieńskie, like many other villages in the West Pomeranian Voivodship, particularly suffered the process of political changes in the early 1990s. The liquidation of state-owned farms and other jobs has contributed to the increase in unemployment and long-term economic stagnation. Unfavorable economic situation also negatively affected the level of aesthetics and infrastructure of the village in question.

The situation began to change at the beginning of the 21st century. In 2000, as part of the Sianów Commune Development Strategy, the idea of founding a theme village was born. The village modeled on the previously tested solutions used, among others in Austria, and its key asset was to be a picturesque location close to wooded areas. In addition to residents, in the creation of the village they helped, among others Tolkien prose lovers, students, scouts, artists (Idziak 2009).

The main reason for the investment was to make the local tourist offer more attractive and stimulate the activity of the unemployed. The theme and inspiration that made the village come into being are J.R.R. novels Tolkien - The Lord of the Rings trilogy and The Hobbit. In 2003, the Hobbiton Association was established, which currently has about 40 people. Mieczysław Juszczyk is the president of the association. Its members are mainly residents of the village of Sierakowo Sławieńskie, who are directly or indirectly involved in its service. They constitute a significant percentage of all inhabitants of the village, which numbers about 200 people. Tourists' interest in the village dates back to 2003.

Thanks to the activities of the Hobbiton Association, they built facilities within the village itself (including Bilbo Baggins' House, Elf Tower, Dragon's Chamber, Tavern under a frisky pony or Palantir) as well as facilities outside the village for outdoor games (Dead Swamps, Dwarf Forge, Elf Forest).

About 20 residents of Sieraków Sławieński are directly involved in the functioning of the theme village. They treat their occupation as additional or seasonal work. Another 20 people support the village in various ways (marketing, promotion, running the village website). The theme village and its staff earn a living by organizing field games and workshops for participating in which small fees are charged (Table 3). Employees are also involved in guiding guests, selling souvenirs, preparing meals and playing fairy-tale characters.

Table 3. Tourist offer of the Hobbit Village.

\begin{tabular}{cccc}
\hline Name & Description & $\begin{array}{c}\text { Number of participants } \\
\text { and duration }\end{array}$ & $\begin{array}{c}\text { Payment with meals in } \\
\text { polish zlotys }\end{array}$ \\
\hline $\begin{array}{c}\text { Dragon Egg Team } \\
\begin{array}{c}\text { The Hobbit, which } \\
\text { is back and forth }\end{array}\end{array}$ & Field role-playing game & Above 15 people, 3 h & $20 \mathrm{zł}$ \\
\hline
\end{tabular}




\begin{tabular}{cccc}
\hline $\begin{array}{c}\text { Expedition through } \\
\text { the Dark Forest } \\
\text { Workshops }\end{array}$ & Bicycle field game & Above 20 people, 4h & $25 \mathrm{zl}$ \\
\hline
\end{tabular}

The tourist offer is adapted to various age groups, physical abilities of participants and their interests. According to Grażyna Pełech, a co-founder and employee of the discussed village, their implementation involves 2 to 10 people, with the Hobbit, i.e. back and forth, enjoying the greatest interest. Guests also decide whether or not to use the local gastronomic offer.

However, in order to attract tourists and visitors, the Hobbit Village organizes cyclical events:

- Hobbit run,

- Hobbit fair,

- Sunday picnic.

Since then, "Hobbiton" is an attraction that is visited by thousands of tourists from all over Poland and abroad every year, as shown in Table 4.

Table 4. Estimated number of people visiting the Hobbit village in selected years in thousands.

\begin{tabular}{cc}
\hline Year & Number of tourists \\
\hline 2003 & 15000 \\
2006 & 10000 \\
2008 & 10000 \\
2010 & 15000 \\
2013 & 10000 \\
2015 & 8000 \\
2019 & 6000 \\
\hline
\end{tabular}

Source: Hobbiton Association data.

The data contained in Table 4 indicate the variability in the number of visitors to the theme village. According to the president of the Hobbiton Association Mieczysław Juszczyk, the variable number of people visiting the village of Hobbits results from the fact that new thematic villages appear in the area, which of course is somewhat competitive. In addition, the village of Hobbits, which has been operating for almost 20 years, has become a well-known attraction in the area. Mieczysław Juszczyk points out that, like every tourist attraction, the Hobbit village also requires revitalization and conservation work. It is also necessary to expand the existing tourist offer in the face of growing competition.

Further plans are proof of the continuous development of this village. Currently, the village is preparing for the implementation of another project called "Sensory Garden". As part of the aforementioned undertaking, another interesting tourist attraction will be created, aimed at making the stay more attractive by providing participants with acoustic and tactile sensations. The new offer means new jobs and sources of earnings.

According to tourists, the biggest advantage of the Hobbit Village is to create fun for both adults and children. In addition, visitors pointed out the possibility of combining both sightseeing and participation in workshops, many of which were completely new to them (the art of decupage, making decorations by the method of quilling). For some visitors, the greatest attraction were educational values, manual classes and agility games.

\section{Discussion}

The functioning of thematic villages in the West Pomeranian Voivodeship, just like in other regions in Poland, is a unique opportunity to stimulate the development of entrepreneurship and activation of local communities without harming the natural environment. The main benefit for the 
villagers is the possibility of obtaining income on the spot, using the existing potential and assets. Joint work also contributes to maintaining mutual neighbors and creating new ideas. To this should be added the income increase of entities constituting the immediate environment (transport companies, grocery stores, service outlets). It is also worth mentioning the positive impact on the level of aestheticization of the village, infrastructure and presence in the media and public awareness.

The idea of thematic villages found fertile ground and many other villages follow the example of pioneers. Their further effective development depends on effective management as well as on further extending and making the functioning offer more attractive. Such activities will have a positive impact on the competitiveness of thematic villages and the cyclical nature of visiting them.

\section{References}

Bański Jerzy. 2017. Rozwój obszarów wiejskich. Wybrane zagadnienia. Warszawa: PWE.

Biziuk Dorota. 2009. Wioski tematyczne: inny świat. Available online: https://wspolczesna.pl/wioski-tematyczneinny-swiat/ar/5665962 (accessed on 4 May 2019).

Czapiewska Gabriela. 2011. Wpływ środków Unii Europejskiej na pobudzenie inicjatyw społeczności wiejskich obszarów peryferyjnych województwa zachodniopomorskiego. In Wiejskie obszary peryferyjne- uwarunkowania i czynniki aktywizacji. Warszawa: IRWiR PAN, Vol. 26, pp. 233-248.

Gangewere R. Jay. 1999. Theme City: Imagining Pittsburgh. Available online: http://www.carnegiemuseums.org/cmag/bk_issue/1999/sepoct/feat6.html (accessed on 14 August 2019).

GUS. 2010. Mały rocznik statystyczny polski. Available online: https://stat.gov.pl/cps/rde/xbcr/gus/oz_maly_rocznik_statystyczny_2010.pdf (accessed on 30 July 2016).

GUS. 2017. Raport GUS. Available online: https://stat.gov.pl/aktualnosci/raport-gus-2016,152,1.html (accessed on 06 January 2017).

GUS. 2019. Zestawy danych. Available online: http://form.stat.gov.pl/formularze/2019/index.html (accessed on 15 December 2019).

Idziak Wacław. 2008. Wymyślić wieś od nowa: wioski tematyczne. Koszalin: Fundacja Wspomagania Wsi.

Idziak Wacław. 2004. O odnowie wsi. Warszawa: Fundacja Wspomagania Wsi.

Idziak Wacław. 2009. Fundusze europejskie na lata 2007-2013. Available online: https://www.funduszeeuropejskie.2007-2013.gov.pl/1/Lider/osoby/Strony/kandydat_115.aspx

December 2018)

Jasiulewicz Michał. 2011. Problemy marginalizacji popegeerowskich obszarów wiejskich w województwie zachodniopomorskim. Barometr Regionalny: 2011, 33-39.

Kamieńska Wioletta. 2015. Innowacyjność w turystyce wiejskiej a nowe możliwości zatrudnienia na obszarach wiejskich. Warszawa: Polska Akademia Nauk, Komitet Przestrzennego Zagospodarowania Kraju.

Kapusta Franciszek. 2008. Agrobiznes. Warszawa: Difin.

Knecht Damian. 2009. Agroturystyka w agrobiznesie. Warszawa: C.H. Beck.

Krajewski Krzysztof, and Śliwa Jan. 2004. Lokalna przedsiębiorczość w Polsce: Uwarunkowania rozwoju. Warszawa: Naukowe Zarządzania Uniwersytetu Warszawskiego.

Mocek Andrzej. 2015. Gleboznawstwo. Warszawa: Wydawnictwo Naukowe PWN.

Pilichowski Andrzej, and Podedworna Hanna. 2011. Obszary wiejskie w Polsce. Różnorodność i procesy różnicowania. Warszawa: IFiS PAN.

PSEW. Available online: http://psew.pl/ (accessed on 18 December 2019)

Rudewicz Jacek. 2017. Motywy osiedlania się Polaków w niemieckiej części obszaru funkcjonalnego miasta Szczecin. Studium przypadku miejscowości Löcknitz. Przedsiębiorczość - Edukacja: 13, 86-105 10.24917/20833296.13.7

Rumiński J. Marek. 2002. Pojezierze zachodniopomorskie. Bia·lystok: Agencja "TD".

Sala Krzysztof. 2016. Wioski tematyczne jako przykład innowacyjności w turystyce wiejskiej. Kraków: Małopolskiej Wyższej Szkoły Ekonomicznej.

Sikora Jan. 2012. Agroturystyka. Przedsiębiorczość na obszarach wiejskich. Warszawa: C.H. Beck.

Smętkowski Maciej, Jałowiecki Bohdan, and Gorzelak Grzegorz. 2008. Diagnoza problemów rozwoju obszarów metropolitalnych i rekomendacja delimitacji obszarów metropolitalnych w Polsce, Centrum Europejskich Studiów Regionalnych i Lokalnych (EUROREG). Warszawa: Uniwersytet Warszawski. Availanble online: www.gus.gov.pl (accessed on 30 October 2018). 
Zielazna Joanna. 2016. Ptasia, grzybowa, miodowa czy mydlarska. Mieszkańcy mają pomysły jak do wsi przyciągnąć turystów. Available online: https://plus.pomorska.pl/ptasia-grzybowa-miodowa-czymydlarska-mieszkancy-maja-pomysly-jak-do-wsi-przyciagnac-turystow/ar/10502584 (accessed on 14 August 2019) 